\section{Molecular and Cellular Biology}

New human transforming genes detected by a tumorigenicity assay.

O Fasano, D Birnbaum, L Edlund, J Fogh and M Wigler

Mol. Cell. Biol. 1984, 4(9):1695. DOI: 10.1128/MCB.4.9.1695.

Updated information and services can be found at:

http://mcb.asm.org/content/4/9/1695

These include:

CONTENT ALERTS

Receive: RSS Feeds, eTOCs, free email alerts (when new articles cite this article), more» 


\title{
New Human Transforming Genes Detected by a Tumorigenicity Assay
}

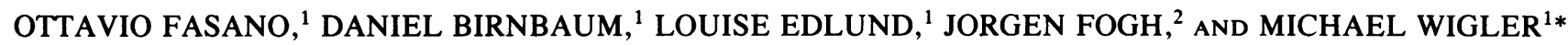 \\ Cold Spring Harbor Laboratory, Cold Spring Harbor, New York $11724,{ }^{1}$ and Sloan Kettering Institute, Rye, New York \\ $10580^{2}$
}

Received 20 April 1984/Accepted 1 June 1984

\begin{abstract}
We have developed a sensitive bioassay for transforming genes based on the tumorigenicity of cotransfected NIH3T3 cells in nude mice. The assay differs substantially from the NIH3T3 focus assay. Using it, we have detected the transfer of three transforming genes from the DNA of MCF-7, a human mammary carcinoma cell line. One of these is N-ras, which is amplified in MCF-7 DNA. The other two, which we have called mcf 2 and $m c f 3$, do not appear to be related to known oncogenes. We cannot detect their transfer by using the NIH3T3 focus assay. We do not yet know whether either $m c f 2$ or $m c f 3$ is associated with genetic abnormalities in MCF-7 cells.
\end{abstract}

The transfer of genomic DNA into NIH3T3 cells has led to the discovery that genes present in some tumor cells are capable of inducing foci of morphologically transformed NIH3T3 cells $(24,27,31,33,40)$. Most of the transforming genes which have been detected this way have now been identified as members of the ras gene family, either $\mathrm{H}-, \mathrm{K}-$, or $\mathrm{N}$-ras $(8,17,29,33,36,43)$. The transforming ras genes detected by the NIH3T3 focus assay have structural gene mutations that account for their transforming activity $(34$, $48,50,51,55)$. Since the great majority of tumor DNAs tested fail to induce transformed foci $(24,31,33)$, we have speculated that the focus assay has a bias for ras genes containing structural mutations. Therefore, we have begun a series of experiments to explore alternative assays for transforming genes present in NIH3T3 cells after DNA transfer. We describe here some preliminary results with an assay system that detects new oncogenes. The system is a modification of the one described by Blair and co-workers (2). Like theirs, our assay also relies on the ability of transformed NIH3T3 cells to form tumors in nude mice, but incorporates methods of cotransfection (54) to heighten sensitivity. Using this assay, we have transferred three human transforming genes from the DNA of MCF-7, a human breast carcinoma cell line. One of these is $\mathrm{N}$-ras. The other two appear to be unrelated to previously known transforming genes. The $\mathrm{N}$ ras gene is amplified in MCF-7 cells but does not appear to contain structural mutations. We have not yet established whether the other two genes, which we have called $m c f 2$ and $m c f 3$, are associated with any genetic abnormality in MCF7.

\section{MATERIALS AND METHODS}

Preparation and source of DNA. High-molecular-weight DNA from various cell lines was prepared as described previously (31). MCF-7 was from the Human Tumor Cell Line Bank of the Sloan Kettering Institute, Rye, N.Y. (44). Preparation of DNA from solid tumors was done as follows. Tumors ( 1 to $2 \mathrm{~g}$ of frozen tissue) were finely ground by using a pestle in a mortar containing liquid $\mathrm{N}_{2}$. The resulting powder was added to $40 \mathrm{ml}$ of $400 \mathrm{mM} \mathrm{NaCl}-10 \mathrm{mM}$ EDTA$20 \mathrm{mM}$ Tris-hydrochloride ( $\mathrm{pH} 7.5$ ) $-0.5 \%$ sodium dodecyl sulfate prewarmed at $68^{\circ} \mathrm{C}$ and incubated at this temperature

\footnotetext{
* Corresponding author
}

for $20 \mathrm{~min}$. An additional incubation at $37^{\circ} \mathrm{C}$ in the presence of proteinase $\mathrm{K}$ at the final concentration of $200 \mu \mathrm{g} / \mathrm{ml}$ was carried out with very slow agitation for 24 to $48 \mathrm{~h}$. Phenol extraction and subsequent steps were as described previously (31). Plasmid and phage DNAs were prepared by published methods $(21,49)$. Many plasmids that were used in this study were generously provided by the following scientists: pKOneo, D. Hanahan; psrc-11, G. Cooper; pBR-Y73, N. Kitamura; pAB-sub3, S. Goff; pGA-FeSV, C. Sherr; pRCII-1B, H. Hanafusa; pBR-UR2, H. Hanafusa; pAEPvuII, M. Bishop; pHB-11, E. Scolnick; pKBE-2, E. Scolnick; pm-1, D. Blair; pMCV38, M. Bishop; pVM-2, M. Bishop; pFBJ-2, I. Verma; pSSV-11, S. Aaronson; pREVT3, H. Temin; pvski-1, E. Stavnezer; pMT-2.5, H. Varmus; pSM-FeSV, C. Sherr; and blur 8, C. Schmid. Phage $\lambda$ myc4.1.1 was from M. Cole.

DNA transfections and nude mice assay. All DNA transfers used a modified calcium phosphate precipitation method (15, 54) with NIH3T3 cells as recipients $(19,31)$. Focus assays were performed as previously described (31). For the nude mouse experiments, $30 \mu \mathrm{g}$ of cellular DNA plus $300 \mathrm{ng}$ of pKOneo plasmid, constructed by D. Hanahan (unpublished data), were added as a calcium phosphate precipitate (volume, $1 \mathrm{ml}$ ) to each $100-\mathrm{mm}$ culture dish containing $5 \times 10^{5}$ cells in $10 \mathrm{ml}$ of Dulbecco medium and $10 \%$ calf serum (D10). After incubation for $8 \mathrm{~h}$, the precipitate was removed and replaced by $10 \mathrm{ml}$ of fresh D10. After an additional $6 \mathrm{~h}$, the cells in each plate were trypsinized and seeded into four 100 $\mathrm{mm}$ dishes containing D10 plus $0.4 \mathrm{~g}$ of the antibiotic $\mathrm{G} 418$ (GIBCO Laboratories) per liter (as calculated for $100 \%$ active antibiotic). This time schedule is critical, since the antibiotic efficiently selects cells expressing the resistance marker only when seeding is done at low cell density. Refeeding of the cultures was done at intervals of 3 days, using the same medium. The plates, each containing about 300 colonies, reached confluency after 16 to 18 days. At this time, the four plates of cells were trypsinized, pooled, centrifuged at $700 \mathrm{rpm}$ for $5 \mathrm{~min}$, and resuspended in $0.25 \mathrm{ml}$ of D10. Approximately $10^{7}$ cells were injected subcutaneously over the right shoulders of athymic, 4- to 8-week-old male or female Nu-Nu mice of Rex-Trembler origin which had been back-crossed to Swiss three times. One deviation from this protocol is described in the footnote to Table 1 .

Tumor growth was monitored weekly, and the mean 
diameter was calculated as the cubic root of the product of its three major diameters. Before death from tumor growth, the mice were sacrificed, and the tumor tissue ( 1 to $3 \mathrm{~g}$ ) was frozen in liquid $\mathrm{N}_{2}$ to obtain DNA at a later time.

Southern filter-blot hybridization. DNA samples were digested with restriction endonucleases and subjected to agarose gel electrophoresis and filter-blot transfer by the method of Southern (45). Filter-blot DNAs were hybridized with nick-translated probes (26) under stringent conditions described previously (43). Nonstringent hybridization conditions entailed use of essentially the same components at $60^{\circ} \mathrm{C}$ instead of $74^{\circ} \mathrm{C}$. When total human or mouse DNA was nick translated and used as a probe, its concentration during hybridization was $0.03 \mu \mathrm{g} / \mathrm{ml}$. For hybridization with ras probes, we nick translated these DNAs: plasmid p6aI, a partial cDNA clone of the human N-ras gene (50); the 3.0kilobase-pair (kbp) EcoRI fragment containing coding exon II of the human K-ras gene (41); and the $0.7-\mathrm{kbp} N a r \mathrm{I}-A v a \mathrm{I}$ fragment from plasmid RS6 (11), a cDNA clone of the human $\mathrm{H}$-ras gene containing most of the coding sequences.

Isolation of $m c f 1, m c f 2$, and $m c f 3$. Genomic libraries of MCF-7 DNA and the secondary tumor DNAs (MCF-7-1-1, MCF-7-2-2, and MCF-7-3-4) were constructed in $\lambda$ charon 4a $(4,18)$ from DNA partially digested with $E c o$ RI and fractionated over a sucrose gradient as described previously (31). To obtain clones of the $m c f$ genes, we screened $5 \times 10^{5}$ phages from libraries of secondary tumor DNAs for human sequences by the method of Benton and Davis (1) using nicktranslated human placental DNA as a probe (16). To obtain $m c f$ clones from MCF-7 DNA, we screened that library with repeat-free fragments of the respective genes. The filter hybridization was performed in $6 \times \mathrm{SSC}-1 \times$ Denhardt $(1 \times$ SSC is $0.15 \mathrm{M} \mathrm{NaCl}$ plus $0.015 \mathrm{M}$ sodium citrate) at $68^{\circ} \mathrm{C}$ for $20 \mathrm{~h}$ followed by five washings in $2 \times \mathrm{SCC}$ at $68^{\circ} \mathrm{C}$.

\section{RESULTS}

Assays with MCF-7 DNA. In brief, the new assay is performed as follows. NIH3T3 cells are cotransfected with cellular DNA and DNA of the pKOneo plasmid, which renders animal cells resistant to the antibiotic G418 (46). In each experimental group, about $10^{3}$ G418-resistant colonies containing about $10^{4}$ cells are present after 2 to 3 weeks. These are pooled and injected into one nude mouse. The time of the first appearance of tumors and their subsequent growth is noted. As a positive control, one set of mice is inoculated with NIH3T3 cells exposed to genomic DNA from a1-1, an NIH3T3 transformant containing a high copy number of the transforming human H-ras gene of T24 bladder carcinoma cells $(14,31)$. As a negative control, one set of mice is inoculated with cells exposed to genomic DNA from NIH3T3 cells. Mice are maintained for up to 3 months.

Our first experiments with the tumorigenicity assay were performed with DNA from a human breast carcinoma cell line, MCF-7. Lane et al. had previously reported MCF-7 DNA to be positive in the NIH3T3 focus assay (25). However, we had consistently failed to observe any induced foci when using this DNA as donor. Nevertheless, we did obtain positive results using MCF-7 DNA in the nude mouse assay (Tables 1 and 2). In two experiments, three independent tumors were obtained. There was a low tumor incidence in the negative control group (see tables) as well as in mice injected with NIH3T3 cells exposed to human placental DNA (data not shown). There is, therefore, a background of tumor induction when testing normal DNA, a point to which we will return later. With MCF-7 DNA, as with many other tumor DNAs we have since examined, tumor incidence was higher than with control DNAs, but this may not be statistically significant. We therefore do not assume that the positive results with MCF-7 DNA reflect a genetic abnormality in MCF-7 cells. The assay is, however, clearly responsive to high copies of strongly transforming genes since tumor incidence is markedly increased with the positive control groups, consisting of nude mice injected with NIH3T3 exposed to DNA from a1-1.

We call tumors resulting from cells exposed to MCF-7 DNA primary tumors MCF-7-1, MCF-7-2, and MCF-7-3. DNAs prepared from the primary tumors were used again in the tumorigenicity assay to obtain secondary tumors. The lineages of the relevant tumors are given in Table 3. In each case, DNA from the primary tumor was significantly more

TABLE 1. Tumorigenicity assay of MCF-7 DNA ${ }^{a}$

\begin{tabular}{|c|c|c|c|c|c|c|c|c|c|c|}
\hline \multirow{2}{*}{$\begin{array}{l}\text { Donor } \\
\text { DNA }\end{array}$} & \multirow{2}{*}{ Group } & \multicolumn{8}{|c|}{ Mean tumor diam (mm) on day: } & \multirow{2}{*}{$\begin{array}{c}\text { Tumor } \\
\text { designation }\end{array}$} \\
\hline & & 14 & 21 & 28 & 35 & 42 & 49 & 56 & 63 & \\
\hline NIH3T3 & A & $\begin{array}{l}0 \\
0 \\
0\end{array}$ & $\begin{array}{l}0 \\
0 \\
0\end{array}$ & $\begin{array}{l}0 \\
0 \\
0\end{array}$ & $\begin{array}{l}0 \\
0 \\
0\end{array}$ & $\begin{array}{l}\mathrm{Tr} \\
\mathrm{Tr} \\
\mathrm{Tr}\end{array}$ & $\begin{array}{r}14.5 \\
6.8 \\
6.6\end{array}$ & $\begin{array}{c}17.0 \\
3.4 \\
0\end{array}$ & $\begin{array}{c}20.0 \\
0 \\
0\end{array}$ & \\
\hline MCF-7 & B & $\begin{array}{l}0 \\
0 \\
0 \\
0 \\
0 \\
0 \\
0\end{array}$ & $\begin{array}{l}9.1 \\
\mathrm{Tr} \\
\mathrm{Tr} \\
\mathrm{Tr} \\
\mathrm{Tr} \\
\mathrm{Tr} \\
\mathrm{Tr}\end{array}$ & $\begin{array}{r}18.8 \\
14.6 \\
12.2 \\
8.4 \\
13.6 \\
9.0 \\
6.6\end{array}$ & $\begin{array}{r}23.3 \\
22.3 \\
21.5 \\
9.2 \\
18.3 \\
16.7 \\
13.6\end{array}$ & 18.4 & & & & $\begin{array}{l}\text { MCF-7-1a } \\
\text { MCF-7-1b } \\
\text { MCF-7-1c } \\
\text { MCF-7-1d } \\
\text { MCF-7-1e } \\
\text { MCF-7-1f } \\
\text { MCF-7-1g }\end{array}$ \\
\hline
\end{tabular}

$\begin{array}{lll}\text { al-1 } & \text { C } & 21.9 \\ & & 20.2 \\ & & 15.1\end{array}$

\footnotetext{
a Tumorigenesis assays were performed essentially as described in the text. NIH3T3 cells were exposed to both pKOneo and DNA from the indicated cell line and then selected for G418 resistance. Two weeks later, surviving colonies were trypsinized, pooled, and injected into animals. Each group represents a pool of G418-resistant cells. Each line represents a single nude mouse injected with ca. $5 \times 10^{6}$ cells from the equivalent of four plates. al-1 is an NIH3T3 transformant with a high copy number of a transforming H-ras gene $(14,31)$. MCF-7 is a human breast cancer cell line (44). Tumors designated MCF-7-1a through MCF-7-1g all derived from the same initial transformed NIH3T3 cell since they display identical Southern blot patterns when probed from human repeat sequences (data not shown). This is consistent with their origin from a single pool of transformants. These tumors are referred to collectively as MCF-7-1. In subsequent experiments, we avoided this problem by injecting each mouse with an independent pool of transformed cells. See text for more details.
} 
TABLE 2. Tumorigenicity assay of MCF-7 and primary tumor DNAs ${ }^{a}$

\begin{tabular}{|c|c|c|c|c|c|c|c|c|c|c|}
\hline \multirow{2}{*}{$\begin{array}{l}\text { Donor } \\
\text { DNA }\end{array}$} & \multirow{2}{*}{ Group } & \multicolumn{8}{|c|}{ Mean tumor diam $(\mathrm{mm})$ on day: } & \multirow{2}{*}{$\begin{array}{c}\text { Tumor } \\
\text { designation }\end{array}$} \\
\hline & & 13 & 20 & 27 & 34 & 41 & 48 & 55 & 61 & \\
\hline \multirow[t]{7}{*}{ NIH3T3 } & A1 & 0 & 0 & 0 & 0 & 0 & 0 & 0 & 0 & \\
\hline & A2 & 0 & 0 & 0 & $\mathbf{0}$ & 0 & 0 & $\mathbf{0}$ & 0 & \\
\hline & A3 & 0 & 0 & 0 & 0 & 0 & 0 & 0 & 0 & \\
\hline & A4 & $\mathbf{0}$ & 0 & $\mathbf{0}$ & 0 & 0 & 0 & 0 & 0 & \\
\hline & A5 & 0 & 0 & 0 & 0 & 0 & 0 & 0 & 0 & \\
\hline & A6 & 0 & 0 & 0 & 0 & 0 & 0 & 0 & 0 & \\
\hline & A7 & $\mathbf{0}$ & $\mathbf{0}$ & 0 & $\mathbf{0}$ & $\mathbf{0}$ & 0 & 0 & 0 & \\
\hline \multirow[t]{7}{*}{ MCF-7 } & B1 & 0 & 0 & 0 & 0 & 0 & 0 & 0 & 0 & \\
\hline & B2 & 0 & 0 & 0 & 0 & 0 & 0 & 0 & 0 & \\
\hline & B3 & 0 & 0 & $\operatorname{Tr}$ & 9.7 & 12.1 & 15.4 & & & MCF-7-2 \\
\hline & B4 & 0 & 0 & 0 & 0 & 0 & 0 & 0 & 0 & \\
\hline & B5 & 0 & 0 & 0 & 0 & 0 & 0 & 0 & 0 & \\
\hline & B6 & 0 & 0 & 0 & 0 & 0 & 0 & 0 & 0 & \\
\hline & B7 & $\mathbf{0}$ & 0 & 0 & $\operatorname{Tr}$ & 14.7 & 22.4 & & & MCF-7-3 \\
\hline \multirow[t]{7}{*}{ MCF-7-1 } & $\mathrm{Cl}$ & $\mathbf{0}$ & 0 & $\mathbf{0}$ & $\operatorname{Tr}$ & 6.3 & 10.6 & 18.6 & & MCF-7-1-2 \\
\hline & $\mathrm{C} 2$ & 0 & 0 & 0 & 0 & 0 & $\operatorname{Tr}$ & 6.6 & 12.1 & MCF-7-1-7 \\
\hline & C3 & 0 & 0 & 0 & 0 & $\operatorname{Tr}$ & 8.1 & 15.4 & & MCF-7-1-3 \\
\hline & $\mathrm{C} 4$ & 0 & 0 & 0 & 5.1 & 11.0 & 17.2 & & & MCF-7-1-1 \\
\hline & $\mathrm{C} 5$ & 0 & 0 & 0 & 0 & 0 & 5.8 & 10.4 & 9.6 & MCF-7-1-5 \\
\hline & C6 & 0 & 0 & 0 & 0 & $\operatorname{Tr}$ & 7.9 & 16.5 & & MCF-7+1-4 \\
\hline & $\mathrm{C7}$ & 0 & 0 & 0 & 0 & 0 & 4.5 & 7.4 & 12.5 & MCF-7-1-6 \\
\hline \multirow[t]{3}{*}{ al-1 } & D1 & 14.4 & 22.8 & & & & & & & \\
\hline & D2 & 10.2 & 20.8 & & & & & & & \\
\hline & D3 & 13.1 & 25.9 & & & & & & & \\
\hline
\end{tabular}

${ }^{a}$ See Table 1, footnote $a$, and the text. Each group represents an independent pool of transformants and each line a nude mouse inoculated with ca. $10^{7}$ cells.

active at inducing tumorigenic NIH3T3 than the original MCF-7 DNA itself (see, for example, Table 2). This probably results from the amplification of the transforming gene in primary transformants (see below). Despite their higher activity in the nude mouse assay, DNAs from primary tumors still cannot induce foci of morphologically altered NIH3T3 cells. This reflects, we think, an intrinsic difference between the present assay and the focus assay.

DNAs from primary and secondary tumors were prepared and analyzed by Southern blotting for the presence of human repetitive sequences (Fig. 1). This powerful method allows the comparison of our putative transforming genes before their actual isolation $(27,31)$. All secondary tumors derived from the same primary tumor DNA contained a common set of human repetitive sequences. However, these sets differed among secondary tumors derived from different primary tumor DNAs. From this observation we conclude that the nude mouse assay appears to detect three different transforming genes in the DNA of MCF-7 which we called $m c f l$, $m c f 2$, and $m c f 3$. This conclusion was confirmed by subsequent experiments, described below.

Relation of $m c f$ genes to the known ras genes. DNAs from the three primary tumors were analyzed for the presence of the three human ras genes, $\mathrm{N}-, \mathrm{H}-$, and $\mathrm{K}-$ ras, by Southern analysis. Neither MCF-7-2 nor MCF-7-3 contained these genes. Later studies showed that indeed the $m c f 2$ and $m c f 3$ genes are not even weakly related to members of the ras gene family (see below).

DNA from MCF-7-1, however, contained 30 to 100 copies of the human N-ras gene (Fig. 2). Moreover, all secondary tumors derived from MCF-7-1 DNA contained a similar number of copies of the human N-ras gene. Therefore, $m c f l$ was N-ras. Although EcoRI fragments with homology to N- ras are seen in the MCF-7-1 secondary DNAs, they are not the expected size. We cloned the $\mathrm{N}$-ras gene from one of these DNAs (MCF-7-1-1) and analyzed its structure. It contained the 9.2-kbp fragment, which corresponds to the intact $5^{\prime}$ end of the $\mathrm{N}$-ras gene $(50)$, but had undergone rearrangement in sequences which flanked the $3^{\prime}$ end of the gene. We next examined the possibility that the $\mathrm{N}$-ras gene of MCF-7 was itself rearranged. We performed Southern blot analysis of MCF-7 DNA with an N-ras probe and observed that this gene was not rearranged, at least within the 16.3-kbp region containing a functional $\mathrm{N}$-ras gene. This was definitely established by the cloning of the N-ras region from MCF-7 DNA. We conclude that rearrangement of the

TABLE 3. Lineages of tumors grown in nude mice ${ }^{a}$

\begin{tabular}{|c|c|}
\hline $\begin{array}{c}\text { Tumor } \\
\text { designation }\end{array}$ & $\begin{array}{l}\text { Induced by } \\
\text { DNA } \\
\text { from: }\end{array}$ \\
\hline MCF-7-1 . & MCF-7 \\
\hline MCF-7-1-1. & MCF-7-1 \\
\hline MCF-7-1-2. & MCF-7-1 \\
\hline MCF-7-1-3. & MCF-7-1 \\
\hline MCF-7-2 . & MCF-7 \\
\hline MCF-7-2-1. & MCF-7-2 \\
\hline MCF-7-2-2. & MCF-7-2 \\
\hline MCF-7-3 . & MCF-7 \\
\hline $\begin{array}{l}\text { MCF-7-3-1. } \\
\text { MCF-7-3-2 }\end{array}$ & MCF-7-3 \\
\hline $\begin{array}{l}\text { MCF-7-3-2. } \\
\text { MCF-7-3-4. }\end{array}$ & $\begin{array}{l}\text { MCF-7-3 } \\
\text { MCF-7-3 }\end{array}$ \\
\hline
\end{tabular}

${ }^{a}$ The tumors to which we refer by name in the text are listed, together with the cell or tumor DNA which was used to induce them. 


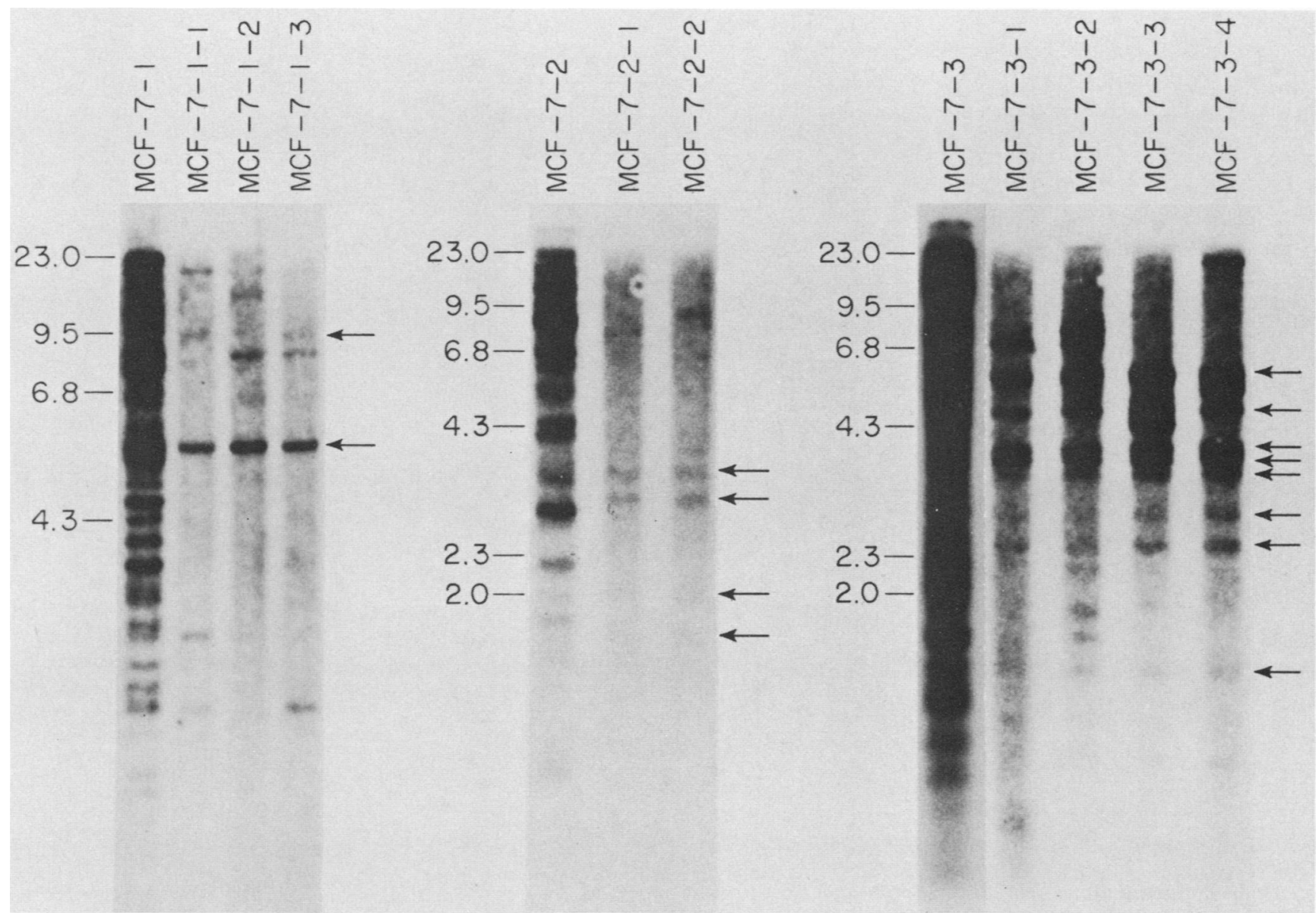

FIG. 1. Human repeat sequences in transformants. DNAs $(10 \mu \mathrm{g}$ each) from the indicated tumors were digested with EcoRI and analyzed by Southern hybridization for the presence of human repeat sequences under conditions of high stringency. Total nick-translated human DNA was used as a probe. Numbers on the left are molecular weight markers in kilobases. Arrows indicate restriction endonuclease fragments with human repeat sequences which have been consistently transferred into secondary transformants.

$\mathrm{N}$-ras gene in NIH3T3 transformants therefore occurred during or after gene transfer. Such rearrangements are common events during gene transfer $(14,30)$.

These same studies, however, did indicate that the N-ras gene of MCF-7 is present at several times the copy number found in normal human diploid cells (Fig. 2). These blot hybridization experiments were repeated several times with

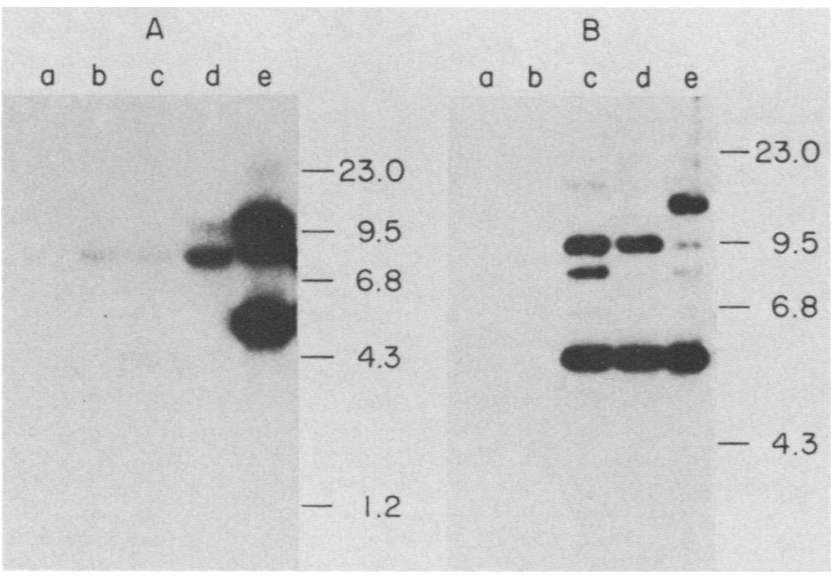

the same results. We carefully monitored the amount of DNA loaded per slot by ethidium bromide staining and UV illumination of the agarose gel before DNA transfer onto nitrocellulose. After hybridizing nitrocellulose filters with nick-translated $\mathrm{N}$-ras probes and performing an autoradiographic exposure, we monitored the amount of DNA transferred from gels by rehybridizing these filters with nick-

FIG. 2. Presence of $\mathrm{N}$-ras in transformants and MCF-7. Various DNAs $(10 \mu \mathrm{g}$ each) were digested with EcoRI and analyzed by Southern hybridization for the presence of the N-ras gene. The partial cDNA clone p6aI (50) was nick translated and used as a probe. This probe hybridizes more strongly with the 3' EcoRI fragment of N-ras than with the 5' EcoRI fragment (50). (A) Lane a, NIH3T3 DNA; lane b, DNA from a normal human fibroblast cell line, GM2998; lane c, DNA from a human placenta; lane d, DNA from MCF-7 cells; lane e, DNA from the primary tumor MCF-7-1. Nitrocellulose filters were exposed for $24 \mathrm{~h}$ at $-70^{\circ} \mathrm{C}$ with intensifying screens. (B) Lane a, DNA from primary tumor MCF-7-2; lane b, DNA from primary tumor MCF-7-3; lane c, DNA from primary tumor MCF-7-1; lane d, DNA from secondary tumor MCF-7-1-2; lane e, DNA from secondary tumor MCF-7-1-3. The hybridizations were done at high stringency. Exposure was for $12 \mathrm{~h}$. Numbers on the right are DNA molecular weight markers in kilobases. 
translated total human DNA and performing a second autoradiographic exposure. These studies indicated that $\mathrm{N}$ ras was present in MCF-7 cells at 5 to 10 times the levels seen in cultured diploid human fibroblasts and human placental cells.

Induction of tumors with ras genes encoding normal proteins. We were surprised to find that DNA from MCF-7-1 could not induce morphologically altered foci in NIH3T3 cells. When the $\mathrm{N}$-ras gene was cloned from a tumor induced by MCF-7-1 DNA, it too was unable to induce foci in NIH3T3 cells. Since the focus assay is sensitive to activated ras genes containing structural mutations, we tentatively concluded that the N-ras gene of MCF-7 encodes a normal protein product and, further, that the tumorigenicity assay, unlike the focus assay, is sensitive to cellular genes with the potential to induce tumorigenicity by increased expression of unaltered protein products.
We directly tested this hypothesis by assaying an activated H-ras gene cloned from T24 bladder carcinoma cells (51), a wild-type $\mathrm{H}$-ras gene cloned from human placental cells (51), an activated $\mathrm{N}$-ras gene cloned from SK-N-SH cells (50), and a wild-type N-ras gene cloned from human placental cells (50) (Table 3 ). The results are summarized in Table 4. The structurally mutated, transforming H-ras and N-ras genes efficiently induced tumors. The H-ras and N-ras genes cloned from human placental DNA were much less active but did nevertheless efficiently induce tumors in nude mice. We attribute this to the presence of multiple copies of these genes in NIH3T3 cells after DNA transfer, a hypothesis consistent with the work of others (5), who have shown that cells expressing high levels of the human $\mathrm{H}$-ras gene product are tumorigenic.

It was still possible that the N-ras gene of MCF-7 contained mutations which made it more active in the tumorige-

TABLE 4. Tumorigenicity assays of normal and mutant ras genes ${ }^{a}$

\begin{tabular}{|c|c|c|c|c|c|c|c|c|}
\hline \multirow{2}{*}{ Donor DNA (ng) } & \multirow{2}{*}{ Group } & \multicolumn{7}{|c|}{ Mean tumor diam $(\mathrm{mm})$ on day: } \\
\hline & & 7 & 14 & 21 & 28 & 35 & 43 & 50 \\
\hline \multirow[t]{3}{*}{ NIH3T3 } & Al & 0 & 0 & 0 & 0 & 0 & 0 & 0 \\
\hline & A2 & 0 & 0 & 0 & 0 & 0 & 0 & 0 \\
\hline & A3 & 0 & 0 & 0 & 0 & 0 & 0 & 0 \\
\hline \multirow{3}{*}{ NIH3T3 + H-ras-pT24 (10) } & B1 & 7.8 & 21.5 & & & & & \\
\hline & B2 & 7.3 & 18.7 & & & & & \\
\hline & B3 & 8.4 & 22.8 & & & & & \\
\hline \multirow[t]{3}{*}{ NIH3T3 + H-ras-pP3 (10) } & $\mathrm{C} 1$ & 0 & 0 & 0 & 4.9 & 12.4 & 19.5 & 20.8 \\
\hline & $\mathrm{C} 2$ & 0 & 0 & 0 & 0 & 0 & 8.4 & 16.5 \\
\hline & $\mathrm{C} 3$ & 0 & 0 & 0 & 4.5 & 11.4 & 18.8 & 19.5 \\
\hline \multirow[t]{3}{*}{ NIH3T3 + H-ras-pP3 (100) } & D1 & 0 & 4.2 & 13.2 & 17.7 & & & \\
\hline & D2 & 0 & 4.9 & 14.3 & 20.8 & & & \\
\hline & D3 & 0 & 5.3 & 8.9 & 16.5 & & & \\
\hline \multirow[t]{4}{*}{ NIH3T3 + N-ras-גNS-35 (10) } & E1 & 7.3 & 27.3 & & & & & \\
\hline & E2 & 5.6 & 23.2 & & & & & \\
\hline & E3 & 6.8 & 20.8 & & & & & \\
\hline & E4 & 6.5 & 22.8 & & & & & \\
\hline \multirow[t]{4}{*}{ NIH3T3 + N-ras- $\lambda$ NP-12 (10) } & $\mathrm{F} 1$ & 0 & 0 & 0 & 0 & 0 & 0 & 8.4 \\
\hline & $\mathrm{F} 2$ & 0 & 0 & 0 & $\operatorname{Tr}$ & 5.1 & 12.0 & 15.3 \\
\hline & F3 & 0 & 0 & 0 & 6.2 & 10.2 & 15.8 & 20.3 \\
\hline & F4 & 0 & 0 & 0 & 0 & 0 & 0 & 0 \\
\hline \multirow[t]{4}{*}{ NIH3T3 + N-ras- $\lambda$ NP-12 (100) } & G1 & 0 & 0 & 0 & 9.6 & 15.3 & & \\
\hline & G2 & 0 & 0 & 5.7 & 11.6 & 20.7 & & \\
\hline & G3 & 0 & 0 & 5.8 & 11.2 & 20.0 & & \\
\hline & G4 & 0 & 0 & 3.9 & 8.9 & 15.6 & & \\
\hline \multirow[t]{4}{*}{ NIH3T3 + N-ras- $\lambda \mathrm{MN}-317$ (10) } & $\mathrm{H} 1$ & 0 & 0 & 0 & 0 & 0 & 0 & 0 \\
\hline & $\mathrm{H} 2$ & 0 & 0 & 0 & 0 & 0 & 0 & 0 \\
\hline & $\mathrm{H} 3$ & 0 & 0. & 0. & 0. & 0. & 4.0 & 8.4 \\
\hline & $\mathrm{H} 4$ & 0 & 0 & 0 & 0 & 0 & 7.9 & 18.1 \\
\hline \multirow[t]{4}{*}{ NIH3T3 + N-ras- $\lambda \mathrm{MN}-317$ (100) } & $\mathrm{J} 1$ & 0 & 0 & 0 & 8.4 & 16.5 & 24.6 & \\
\hline & $\mathrm{J} 2$ & 0 & 0 & 0 & 7.6 & 12.5 & 20.8 & \\
\hline & $\mathrm{J} 3$ & 0 & 0 & 0 & $\mathrm{Tr}$ & 7.2 & 15.8 & \\
\hline & $\mathrm{J} 4$ & 0 & 0 & 0 & 8.4 & 15.3 & 20.5 & \\
\hline a1-1 & $\mathbf{K}$ & 10.4 & 18.7 & & & & & \\
\hline
\end{tabular}

${ }^{a}$ In this experiment, each plate of NIH3T3 cells was exposed to the usual concentration of pKOneo and $30 \mu \mathrm{g}$ of NIH3T3 DNA (groups A through J) or al-1 DNA (group K). Moreover, each plate (groups B through J) received the following additions: group B, $10 \mathrm{ng}$ of the transforming human $\mathbf{H}$-ras gene cloned from T24 DNA, called plasmid pT24; groups C and D, 10 and $100 \mathrm{ng}$, respectively, of the wild-type H-ras gene cloned from human placental DNA, called plasmid pP3; group E, $10 \mathrm{ng}$ of the transforming human N-ras gene cloned from SK-N-SH neuroblastoma cells, called $\lambda \mathrm{NS}-35 ;$ groups F and G, 10 and $100 \mathrm{ng}$, respectively, of the wild-type $\mathrm{N}$-ras gene cloned from human placental DNA, called $\lambda \mathrm{NP}-12$; groups $\mathrm{H}$ and $\mathrm{J}, 10$ and $100 \mathrm{ng}$, respectively, of the human N-ras gene cloned from MCF-7-1-1, called $\lambda$ MN-317. 
A

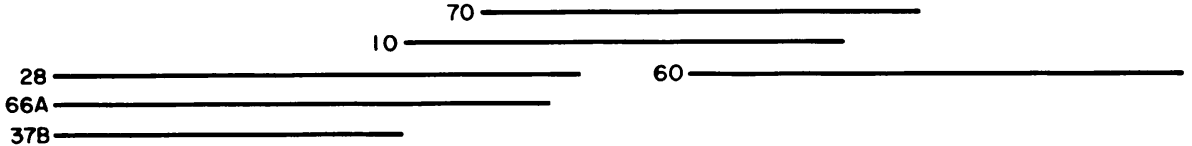

B

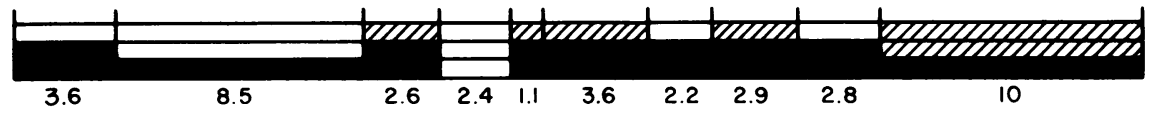

C

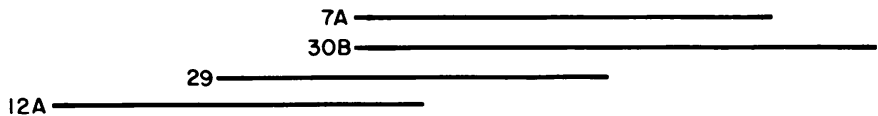

D

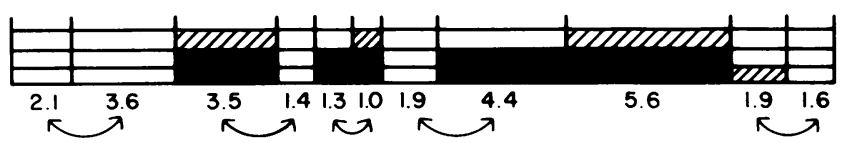

FIG. 3. EcoRI restriction fragments of clones of $m c f 2$ and $m c f 3$. (A and C) EcoRI Inserts of independent $\lambda$ charon 4 a clones of $m c f 2$ and $m c f 3$, respectively. Numbers to the left refer to the $\lambda$ clone designation (for example, clone $\lambda m c f 2-10$ or $\lambda m c f 3-30 \mathrm{~B}$, etc.). (B and D) Composite EcoRI restriction endonuclease map of these genes. Vertical lines indicate EcoRI sites. The relative position of the EcoRI fragments was determined from digests of phages with overlapping inserts. Not all such phages are shown. Ambiguities in relative position are indicated by arrows. Numbers below the fragments are their length in kbp. For each fragment, boxes indicate hybridization signal with total human DNA (lower box), human alu clone blur 8 (20) (middle box), or total mouse DNA (upper box). Solid boxes indicate a strong hybridization signal, slashed boxes indicate a very weak signal, and empty boxes indicate no observable hybridization signal. See Fig. 4 for typical blot hybridization data.

nicity assay but not in the focus assay. However, the $\mathrm{N}$-ras gene cloned from MCF-7-1-1 was no more efficient at inducing tumorigenicity than the $\mathrm{N}$-ras gene cloned from human placental DNA (Table 4). A similar result was obtained when we assayed the $\mathrm{N}$-ras gene cloned directly from MCF-7 DNA (data not shown). These results suggest that the N-ras gene of MCF-7 does not contain significant structural mutations.

Preliminary characterization of the $m c f 2$ and $m c f 3$ genes. We have cloned portions of the two other genes detected by our assay of MCF-7 DNA. We used human repetitive sequences to isolate these genes from $\lambda$ phage libraries we constructed using DNA from secondary tumors MCF-7-2-2 and MCF-7-3-4. In retrospect, this isolation was greatly facilitated by the high copy number of these genes present in induced mouse tumors (see Fig. 5). From overlapping $\lambda$ phage inserts we determined preliminary EcoRI maps of these genes (Fig. 3). We also determined the presence of mouse or human repeat sequences on these genes (Fig. 3 and 4). None of our clones have shown strong hybridization to total nick-translated mouse DNA (Fig. 4D), but we observed weak hybridization between some fragments and mouse DNA upon long autoradiographic exposures (Fig. 4C). We attribute this to weak homology between human and mouse sequences since sequences which were cloned directly from the human cell line MCF-7 also showed this weak hybridization (Fig. 4, lane h). We present this data to facilitate the subsequent unambiguous identification of new oncogenes as they become isolated by others. However, we caution that the human DNA which we have isolated may contain rearrangements. Since none of our phage clones is biologi- cally active in the nude mouse assay, these genes may be too large to clone in a biologically active form as a $\lambda$ phage insert, and we are currently isolating cosmid clones.

By blotting our cloned DNAs with total human or mouse DNA, we identified relatively repeat-free restriction endonuclease fragments useful for Southern hybridization to genomic DNAs. We then were able to examine the copy number of these genes in our various transformants, in MCF-7 cells themselves, and in transformed NIH3T3 cells obtained from G. Cooper which he obtained by using MCF-7 DNA in a focus assay (Fig. 5). Evidently, the $m c f 2$ and $m c f 3$ genes are not related to each other. They are present in high copy numbers in the primary tumors MCF-7-2 and MCF-7-3, respectively, and in the respective secondary tumors derived from them. However, neither gene appears to be amplified in MCF-7 DNA itself. Significantly, neither gene appears to be related to the gene that Lane et al. (25) reported to transfer from MCF-7 DNA to NIH3T3 cells using an NIH3T3 focus assay (Fig. 5, lanes $h$ and $i$ ).

We finally used our cloned DNA as probes to search for homology to known oncogenes. This was done by lowstringency blot hybridization to complete or nearly complete oncogene clones. For probes, we nick translated a total of 39.7 and $28.3 \mathrm{kbp}$ from $m c f 2$ and $m c f 3$, respectively. No homology was seen to the clones of oncogenes shown in Table 5 (blot data not shown). Since this survey includes most of the known cellular oncogenes, we conclude that $m c f 2$ and $m c f 3$ are previously uncharacterized transforming genes. This conclusion must be taken with caution, since we do not know if the cloned portions of the mcf genes include coding sequences. 


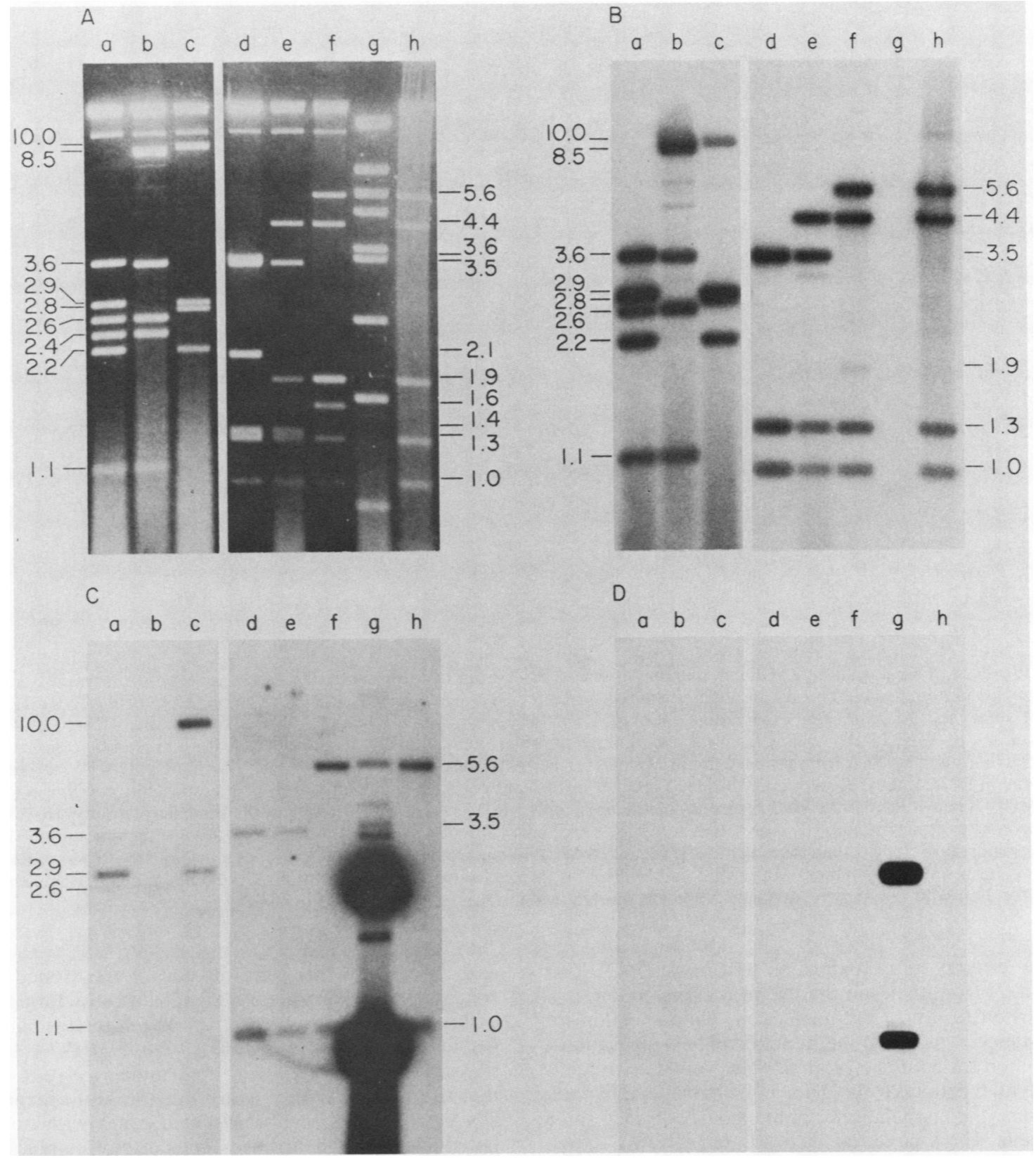

FIG. 4. Hybridization of $\lambda$ phage clones of the $m c f 2$ and $m c f 3$ genes with human and mouse repetitive sequences. (A) Ethidium bromide staining pattern of a $1 \%$ agarose gel loaded with $1.5 \mu \mathrm{g}$ of EcoRI digests of DNA from the following $\lambda$ clones: $\lambda m c f 2-10$, -28 , and -60 (lanes a, b, and c, respectively) from the secondary tumor MCF-7-2-2; $\lambda$ mcf3-12A, -29 , and $-30 \mathrm{~B}$ (lanes d, e, and f, respectively) from the secondary tumor MCF-7-3-4; $\lambda$ mcf3-7A (lane h) from the human cell line MCF-7, which was isolated with an $m c f 3-$ specific probe. Lane $\mathrm{g}$ shows an EcoRI-BamHI digest of $\lambda$ myc4.1.1, a cloned myc gene from mouse plasmacytoma MOPC 315 (39) used as a positive control for mouse repeat sequences. The length of the inserts, indicated except for lane g, is given in kbp. (B, C, and D) Southern blot hybridization of the gel shown in (A) with nick-translated total human DNA after $2 \mathrm{~h}$ of exposure (B) and with nick-translated total mouse DNA after either 4 days (C) or $2 \mathrm{~h}$ (D) of exposure. The hybridizations were done at high stringency (see the text), and exposure was at $-70^{\circ} \mathrm{C}$ with an intensifying screen.

\section{DISCUSSION}

The decision to use tumorigenicity in nude mice rather than focus formation to assay transforming genes was based on two considerations. First, it was clearly at least theoretically possible for altered NIH3T3 cells to be tumorigenic yet unable to form a recognizable focus of morphologically altered cells under conditions of in vitro cultivation. Second, morphologically altered foci of a certain type are sometimes induced in cultures of NIH3T3 in response to the mere physical presence of calcium phosphate-precipitated DNA (31). This background of spontaneous foci potentially obscured detection of certain transforming genes. A similar approach to detecting transforming genes has been described by Blair and co-workers (2), who injected NIH3T3 cells into 


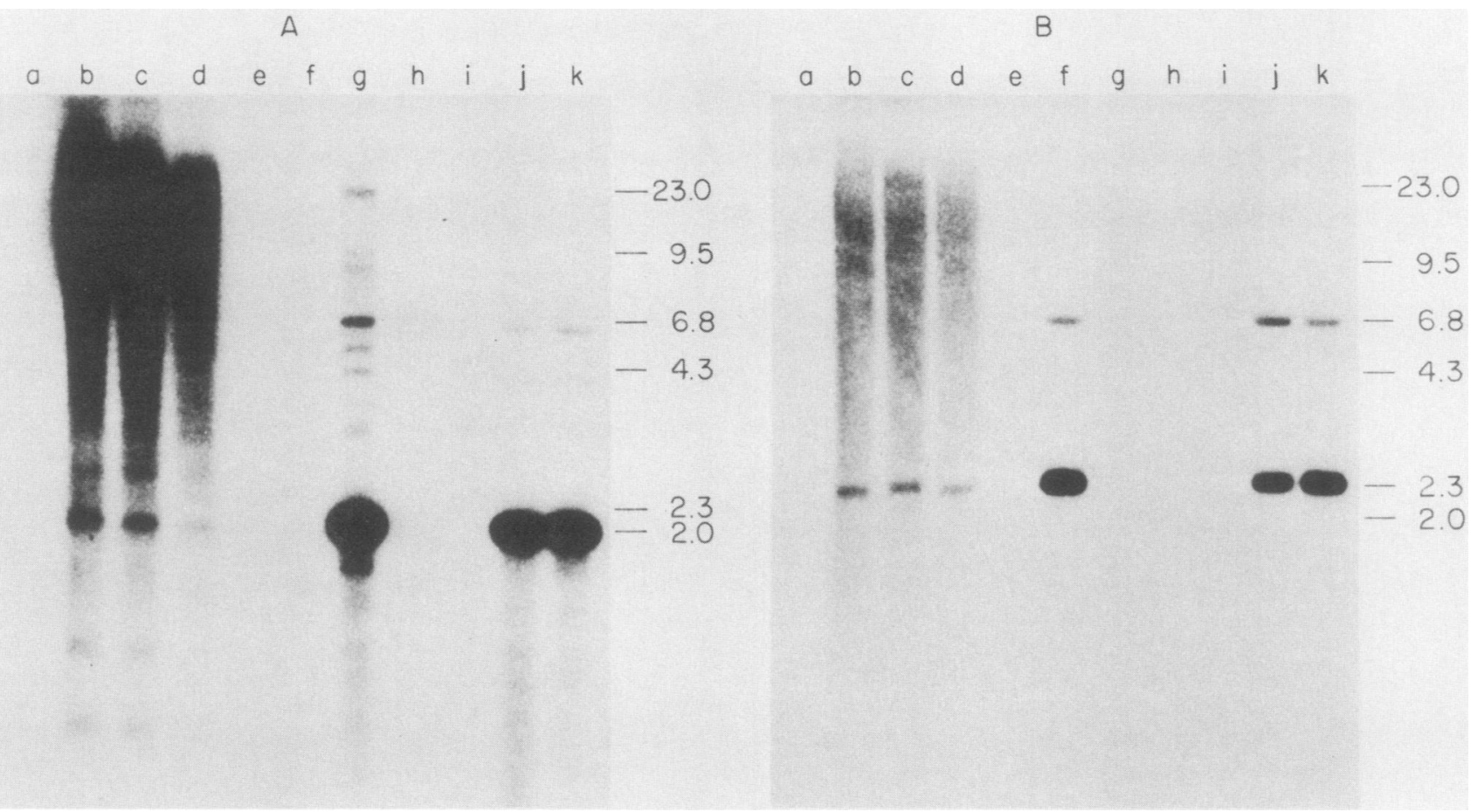

FIG. 5. Presence of $m c f 2$ and $m c f 3$ genes in human DNA and DNA from transformants. DNAs ( $10 \mu g$ each) from various sources were cleaved with EcoRI and analyzed by the method of Southern (45) for DNA sequences homologous to $m c f 3$ (A) or $m c f 2$ (B). Hybridization probes used were: the 1.9-kbp alu-free $E c o$ RI fragment of $m c f 3$ and the 2.4-kbp alu-free fragment of $m c f 2$, respectively (Fig. 3). DNAs were as follows. (A) Lane a, NIH3T3 DNA; lane b, DNA from human fibroblast cells (GM2998); lane c, DNA from human placental cells; lane d, DNA from MCF-7; lane e, DNA from primary tumor MCF-7-1; lane $\mathrm{f}$, DNA from primary tumor MCF-7-2; lane $\mathrm{g}$, DNA from primary tumor MCF-7-3; lane h, DNA from Hu1, a primary NIH3T3 focus transformant obtained from G. Cooper which reportedly contains a transforming gene from MCF-7; lane i, DNA from Hu2, a second, but independent, NIH3T3 focus transformant of the same derivation as Hu1; lane j, DNA from the secondary tumor MCF-7-3-1; lane k, DNA from the secondary tumor MCF-7-3-2. In this experiment, the amount of MCF-7 DNA loaded was proportionately less than the other lanes, as judged by ethidium bromide staining. (B) Lanes a through $i$ were as in (A); lanes $j$ and $\mathrm{k}$ were DNAs from secondary tumors MCF-7-2-1 and MCF-7-2-2, respectively. The hybridizations were done at high stringency. Exposure times were for $24 \mathrm{~h}$ with intensifying screens. Numbers on right are DNA size markers in kbp.

nude mice directly after exposure to tumor DNA. Our method differs from theirs in the use of cotransfection.

The decision to utilize cotransfection, with selection for G418 resistance, was based on the following considerations. First, selection for a biochemical marker preselects for cells competent in the uptake of DNA (54) and effectively removes from the population spontaneously transformed NIH3T3 cells which have not incorporated DNA. Second, from previous studies we know that cells which incorporate a selectable marker are likely to have incorporated, on average, $3 \times 10^{3} \mathrm{kbp}$ from the coprecipitated DNA (32). A total of $10^{3} \mathrm{G} 418$-resistant colonies would likely have incorporated in total, therefore, about $3 \times 10^{6} \mathrm{kbp}$ of coprecipitated DNA, or about one genomic equivalent. Third, by allowing each G418-resistant colony to grow to a size of $10^{4}$ cells, we could in principle detect tumor formation even from weakly tumorigenic cell populations.

Using cotransfer and tumorigenicity in nude mice, we can detect the transfer of three different genes from MCF-7 DNA into NIH3T3 cells which we cannot detect using the focus assay with this DNA as donor. One of the genes which we have transferred from MCF-7 DNA is N-ras. To determine if there are mutations associated with the N-ras gene, we cloned this gene from both MCF-7 and the secondary tumor MCF-7-1-1. These N-ras genes are no more potent in the tumorigenicity assay than an $\mathrm{N}$-ras gene cloned from human placental cells. Although this does not rule out alterations associated with this gene outside of the cloned region, it suggests that there are no significant structural mutations within coding regions. Since the N-ras gene is highly amplified in MCF-7-1-1 and since DNA from MCF-7-1-1 has a high transforming potential in the nude mouse assay, we conclude that the tumorigenicity assay may serve to identify tumor DNAs containing highly amplified genes with transforming potential, even when those genes do not contain structural gene mutations. The tumorigenicity assay differs from the focus assay in this respect, and in fact we have shown that, in a dose-dependent manner, DNAs containing high copy numbers of normal ras genes do induce tumorigenicity.

Our blot hybridization data indicate that the $\mathrm{N}$-ras gene is amplified in MCF-7 cells. In a survey of 10 other human tumors and tumor cell lines (42; unpublished studies) we have not previously observed amplification of the $\mathrm{N}$-ras gene. MCF-7 cells thus have a genetic abnormality associated with N-ras. Amplification of other ras genes, however, has been observed in some tumors and tumor cell lines (14, 37; our unpublished studies).

Two of the genes we have transferred from MCF-7, $m c f 2$ and $m c f 3$, appear to be unrelated to any of the previously identified oncogenes which we have examined. Moreover, an oncogene in MCF-7 cells, detectable after transfer by the NIH3T3 focus assay, was previously reported by Cooper and co-workers (25). Neither the $m c f 2$ nor the $m c f 3$ gene appears to be related to the gene reported by those workers. 
TABLE 5. Molecular clones of oncogenes

\begin{tabular}{|c|c|c|c|}
\hline $\begin{array}{c}\text { Gene } \\
\text { designation }\end{array}$ & Origin & Plasmid & Reference \\
\hline$a b l$ & Abelson murine leukemia virus & pAB-sub3 & 13 \\
\hline$e r b$ & Avian erythroblastosis virus & pAE-PIuII & 52 \\
\hline fes & GA feline sarcoma virus & pGA-FeSV & 12 \\
\hline fos & FBJ osteosarcoma virus & pFBJ-2 & 7 \\
\hline fms & SM feline sarcoma virus & $\mathrm{pSM}-\mathrm{FeSV}$ & 9 \\
\hline fps & PRCII avian sarcoma virus & pRCII-1B & Hanafusa $^{a}$ \\
\hline H-ras & Harvey murine sarcoma virus & pHB-11 & 10 \\
\hline int -1 & Mouse mammary carcinoma & pMT-2.5 & 28 \\
\hline K-ras & Kirsten murine sarcoma virus & pKBE-2 & 10 \\
\hline mos & Moloney murine sarcoma virus & $\mathrm{pm}-1$ & 3 \\
\hline$m y b$ & Avian myeloblastosis virus & pVM-2 & 23 \\
\hline myc & Avian myelocytomatosis & pMCV38 & 53 \\
\hline N-ras & Human neuroblastoma & p6al & 50 \\
\hline rel & Reticuloendotheliosis virus & pRev-T3 & 6 \\
\hline ros & UR2 avian sarcoma virus & pBR-UR2 & Hanafusa $^{a}$ \\
\hline sis & Simian sarcoma virus & pSSV-11 & 35 \\
\hline$s k i$ & Avian SKV770 virus & pvski-1 & Stavnezer ${ }^{\prime \prime}$ \\
\hline$s r c$ & Rous sarcoma virus & psrc-11 & 38 \\
\hline yes & Y73 sarcoma virus & pBR-Y73 & 22 \\
\hline
\end{tabular}

${ }^{a}$ Personal communications. Avian SKV770 virus is described in reference 47.

A more definitive conclusion, however, must await the identification of $m c f 2$ and $m c f 3$ coding regions.

We do not know if the $m c f 2$ and $m c f 3$ genes of MCF-7 cells have genetic abnormalities. On the one hand, it would not be particularly surprising to find multiple weakly transforming genetic lesions in MCF-7 cells or, for that matter, most tumorigenic cells. On the other hand, neither would it be surprising if either or both $m c f 2$ and $m c f 3$ are indeed normal genes which can induce tumorigenicity by overexpression after gene transfer into NIH3T3 cells. To answer these questions, it will be necessary to clone these genes in a biologically active form both from MCF-7 and from normal human DNA to compare their transforming activities.

In summary, we have described a tumorigenicity assay for transforming genes which differs considerably from the NIH3T3 focus assay. We do not fully understand the basis of this difference, nor do we know if the genes we detect with the assay will usually reflect genetic abnormalities in the DNA being tested. Indeed, our results strongly suggest that, with some frequency, normal genes with transforming potential will sometimes be detected. Nevertheless, we appear to have uncovered a previously unknown genetic abnormality in MCF-7 cells and have probably discovered two previously unknown human oncogenes.

\section{ACKNOWLEDGMENTS}

We acknowledge the excellent technical assistance of J. Loveless and L. Ramos.

This work was supported by grants from the National Institutes of Health and the American Business for Cancer Research Foundation and by American Cancer Society Research Development Grant 175. D.B. is supported by Institut National de la Santé et de la Récherche Médicale and Philippe Foundation fellowships. O.F. is on leave from I Istituto di Chimica Biologica, Facolta di Medicina, Universita di Napoli, Italy

\section{LITERATURE CITED}

1. Benton, W. D., and R. W. Davis. 1977. Screening $\lambda$ gt recombinant clones by hybridization to single plaques in situ. Science 196: $180-182$.
2. Blair, D. G., C. S. Cooper, M. K. Oskarsson, L. A. Eader, and G. F. Vande Woude. 1982. New method for detecting cellular transformig genes. Science 281:1122-1125.

3. Blair, D. G., W. L. McClements, M. K. Oskarsson, P. J. Fishinger, and G. F. Vande Woude. 1980. Biological activity of cloned Moloney sarcoma virus DNA: terminally redundant sequences may enhance transformation efficiency. Proc. Natl. Acad. Sci. U.S.A. 77:3504-3508.

4. Blattner, F. R., B. G. Williams, A. E. Blechl, K. DennistonThompson, H. E. Faber, L. A. Furlong, D. J. Grunwald, D. O. Keifer, D. D. Moore, J. W. Schumm, E. L. Sheldon, and 0. Smithies. 1977. Charon phages: safer derivatives of bacteriophage lambda from DNA cloning. Science 196:161-169.

5. Chang, E. H., M. Furth, E. M. Scolnick, and D. R. Lowy. 1982. Tumorigenic transformation of mammalian cells induced by a normal human gene homologous to the oncogene of Harvey murine sarcome virus. Nature (London) 297:479-483.

6. Chen, I., and H. Temin. 1982. Substitution of $5^{\prime}$ helper virus sequences into non-rel portion of reticuloendotheliosis virus strain $\mathrm{T}$ suppresses transformation of chicken spleen cells. Cell 31:111-120.

7. Curran, T., G. Peters, C. Van Beveren, N. M. Teich, and I. M. Verma. 1982. FBJ murine osteosarcoma virus: identification and molecular cloning of biologically active proviral DNA. J. Virol. 44:674-682.

8. Der, C., T. Krontiris, and G. Cooper. 1982. Transforming genes of human bladder and lung carcinoma cell lines are homologous to the ras genes of Harvey and Kirsten sarcoma viruses. Proc. Natl. Acad. Sci. U.S.A. 79:3637-3640.

9. Donner, L., L. A. Fedele, C. F. Garon, S. J. Anderson, and C. J. Sherr. 1982. McDonough feline sarcoma virus: characterization of the molecularly cloned provirus and its feline oncogene (v-fms). J. Virol. 41:489-500.

10. Ellis, R. W., D. Defeo, T. Y. Shih, M. A. Gonda, H. Young, N. Tsushida, D. R. Lowy, and E. M. Scolnick. 1981. The p21 src genes of Harvey and Kirsten sarcoma viruses originated from divergent members of a family of normal vertebrate genes. Nature (London) 292:506-511.

11. Fasano, O., E. Taparowsky, J. Fiddes, M. Wigler, and $M$. Goldfarb. 1983. Sequence and structure of the coding regions of the human H-ras-1 gene from T24 bladder carcinoma cells. J. Mol. Appl. Genet. 2:173-180.

12. Fedele, L. A., J. Even, G. F. Garon, L. Donner, and C. J. Sherr 1981. Recombinant bacteriophages containing the integrated transforming provirus of Gardner-Arnstein feline sarcoma virus. 
Proc. Natl. Acad. Sci. U.S.A. 78:4036-4040.

13. Goff, S. P., E. Gilboa, O. N. Witte, and D. Baltimore. 1980. Structure of the Abelson murine leukemia virus genome and the homologous cellular gene: studies with cloned viral DNA. Cell 22:777-785.

14. Goldfarb, M., K. Shimizu, M. Perucho, and M. Wigler. 1982. Isolation and preliminary characterization of a human transforming gene from T24 bladder carcinoma cells. Nature (London) 296:404-409.

15. Graham, F. L., and A. J. Van der Eb. 1973. A new technique for the assay of infectivity of human adenovirus 5 DNA. Virology 52:456-467.

16. Gusella, J. F., C. Keyus, A. Varsanyi-Breiner, F. T. Kao, C. Jones, T. T. Puck, and D. Housman. 1980. Isolation and localization of DNA segments from specific human chromosomes. Proc. Natl. Acad. Sci. U.S.A. 77:2829-2833.

17. Hall, A., G. J. Marshall, N. K. Spurr, and R. A. Weiss. 1983. Identification of the transforming gene in two human sarcoma cell lines as a new member of the ras gene family located on chromosome 1. Nature (London) 303:396-400.

18. Hohn, B., and K. Murray. 1977. Packaging recombinant DNA molecules into bacteriophage particles in vitro. Proc. Natl. Acad. Sci. U.S.A. 74:3259-3263.

19. Jainchill, J. L., S. A. Aaronson, and G. J. Todaro. 1969. Murine sarcoma and luekemia viruses: assay using clonal lines of contact-inhibited mouse cells. J. Virol. 4:549-553.

20. Jelinek, W. R., T. P. Toomey, L. Leinwand, C. H. Duncan, P. A. Biro, P. V. Choudary, S. M. Weissmann, C. M. Rubin, C. M. Houck, P. L. Deininger, and C. W. Schmid. 1980. Ubiquitous, interspersed repeated sequences in mammalian genomes. Proc. Natl. Acad. Sci. U.S.A. 77:1398-1402.

21. Kaiser, A. D., and D. S. Hogness. 1960. The transformation of Escherichia coli with deoxyribonucleic acid isolated from bacteriophage $\lambda$ dg. J. Mol. Biol. 2:392-415.

22. Kitamura, N., A. Kitamura, K. Toyoshima, Y. Hirayama, and M. Yoshida. 1982. Avian sarcoma virus Y73 genome sequence and structural similarity of its transforming gene product to that of Rous sarcoma virus. Nature (London) 297:205-208.

23. Klempnauer, K. H., G. Ramsey, J. M. Bishop, M. G. Moscovici, C. Moscovici, J. P. McGrath, A. D. Levinson. 1983. The product of the retroviral transforming gene v-myb is a truncated version of the protein encoded by the cellular oncogene c-my $b$. Cell 33:345-355.

24. Krontiris, T. G., and G. M. Cooper. 1981. Transforming activity of human tumor DNAs. Proc. Natl. Acad. Sci. U.S.A. 78:11811184.

25. Lane, M. A., A. Sainten, and G. M. Cooper. 1981. Activation of related transforming genes in mouse and human mammary carcinomas. Proc. Natl. Acad. Sci. U.S.A. 78:5185-5189.

26. Maniatis, T., A. Jeffrey, and D. G. Kleid. 1975. Nucleotide sequence of the rightward operator of phage $\lambda$. Proc. Natl. Acad. Sci. U.S.A. 72:1184-1188.

27. Murray, M. J., B. Z. Shilo, C. Shih, D. Cowing, H. W. Hsu, and R. A. Weinberg. 1981. Three different human tumor cell lines contain different oncogenes. Cell 25:355-361.

28. Nusse, R., A. Van Ooyen, D. Cox, Y. K. T. Fung, and H. Varmus. 1984. Mode of proviral activation of a putative mammary oncogene (int-1) on mouse chromosome 15. Nature (London) 307:131-136.

29. Parada, L. F., C. J. Tabin, C. Shih, and R. A. Weinberg. 1982. Human EJ bladder carcinoma oncogene is homologue of Harvey sarcoma virus ras gene. Nature (London) 297:474-478.

30. Pellicer, A., M. Wigler, R. Axel, and S. Silverstein. 1978. The transfer and stable integration of the HSV thymidine kinase gene into mouse cells. Cell 14:133-141.

31. Perucho, M., M. Goldfarb, K. Shimizu, C. Lama, J. Fogh, and M. Wigler. 1981. Human-tumor-derived cell lines contain common and different transforming genes. Cell 27:467-476.

32. Perucho, M., and M. Wigler. 1980. Linkage and expression of foreign DNA in cultured animal cells. Cold Spring Harbor Symp. Quant. Biol. 45:829-838.

33. Pulciani, S., E. Santos, A. V. Lauver, L. K. Long, K. C. Robbins, and M. Barbacid. 1982. Oncogenes in human tumor cell lines: molecular cloning of a transforming gene from human bladder carcinoma cells. Proc. Natl. Acad. Sci. U.S.A. 79:2845-2849.

34. Reddy, E. R., R. K. Reynolds, E. Santos, and M. Barbacid. 1982. A point mutation is responsible for the acquisition of transforming properties by the T24 human bladder carcinoma oncogene. Nature (London) 300:149-152.

35. Robbins, K. L., S. G. Devare, E. P. Reddy, and S. A. Aaronson. 1982. In vivo identification of the transforming gene product of simian sarcoma virus. Science 218:1131-1133.

36. Santos, E., S. R. Tronick, S. A. Aaronson, S. Pulciani, and M. Barbacid. 1982. T24 human bladder carcinoma oncogene is an activated form of the normal human homologue of BALB- and Harvey-MSV transforming genes. Nature (London) 298:343347.

37. Schwab, M., K. Alitalo, H. Varmus, J. M. Bishop, and D. George. 1983. A cellular oncogene (c-Ki-ras) is amplified, overexpressed, and located within karyotypic abnormalities in mouse adrenocortical tumour cells. Nature (London) 303:497501.

38. Shalloway, D., A. D. Zelenetz, and G. M. Cooper. 1981. Molecular cloning and characterization of the chicken gene homologous to the transforming gene of rous sarcoma virus. Cell 24:531-541.

39. Shen-ong, G., E. Keath, S. Piccoli, and M. Cole. 1982. Novel myc oncogene RNA from abortive immunoglobulin-gene recombination in mouse plasmacytomas. Cell 31:443-452.

40. Shih, C., B. Shilo, M. Goldfarb, A. Dannenberg, and R. Weinberg. 1979. Passage of phenotypes of chemically transformed cells via transfection of DNA and chromatin. Proc. Natl. Acad. Sci. U.S.A. 76:5714-5718.

41. Shimizu, K., D. Birnbaum, M. A. Ruley, O. Fasano, Y. Suard, L. Edlund, E. Taparowsky, M. Goldfarb, and M. Wigler. 1983. The structure of the K-ras gene of the human lung carcinoma cell line Calu-1. Nature (London) 304:497-500.

42. Shimizu, K., M. Goldfarb, M. Perucho, and M. Wigler. 1983. Isolation and preliminary characterization of the transforming gene of a human neuroblastoma cell line. Proc. Natl. Acad. Sci. U.S.A. 80:383-387.

43. Shimizu, K., M. Goldfarb, Y. Suard, M. Perucho, Y. Li, T. Kamata, J. Feramisco, E. Stavnezer, J. Fogh, and M. Wigler. 1983b. Three human transforming genes are related to the viral ras oncogenes. Proc. Natl. Acad. Sci. U.S.A. 80:2112-2116.

44. Soule, H. D., J. Vazquez, A. Long, S. Albert, and M. Brennan. 1973. A human cell line from a pleural effusion derived from a breast carcinoma. J. Natl. Cancer Inst. 51:1409-1416.

45. Southern, E. M. 1975. Detection of specific sequences among DNA fragments separated by gel electrophoresis. J. Mol. Biol. 98:503-517.

46. Southern, P. J., and P. Berg. 1982. Transformation of mammalian cells to antibiotic resistance with a bacterial gene under control of the SV40 early region promoter. J. Mol. Appl. Genet. 1:327-341.

47. Stavnezer, E., D. S. Gerhard, R. C. Binari, and I. Balazs. 1981. Generation of transforming viruses in cultures of chicken fibroblasts infected with an avian leukosis virus. J. Virol. 39:920934.

48. Tabin, C. J., S. M. Bradley, C. I. Bargmann, R. A. Weinberg, A. G. Papageorge, E. M. Scolnick, R. Dhar, D. R. Lowy, and E. H. Chang. 1982. Mechanism of activation of a human oncogene. Nature (London) 300:143-148.

49. Tanaka, T., and B. Weisblum. 1975. Construction of a colicin E1-R factor composite plasmid in vitro: means for amplification of deoxyribonucleic acid. J. Bacteriol. 121:354-362.

50. Taparowsky, E., K. Shimizu, M. Goldfarb, and M. Wigler. 1983. Structure and activation of the human $\mathrm{N}$-ras gene. Cell 34:581586.

51. Taparowsky, E., Y. Suard, O. Fasano, K. Shimizu, M. Goldfarb, and M. Wigler. 1982. Activation of the T24 bladder carcinoma transforming gene is linked to a single amino acid change. Nature (London) 300:762-765.

52. Vennström, B., L. Fanshier, C. Moscovici, and J. M. Bishop. 1980. Molecular cloning of the avian erythroblastosis virus genome and recovery of oncogenic virus by transfection of chicken cells. J. Virol. 36:575-585. 
53. Vennström, B., C. Moscovici, H. M. Goodman, and J. M. Bishop. 1981. Molecular cloning of the avian myelocytomatosis virus genome and recovery of infectious virus by transfection of chicken cells. J. Virol. 39:625-631.

54. Wigler, M., R. Sweet, G. K. Sim, B. Wold, A. Pellicer, E. Lacy, T. Maniatis, S. Silverstein, and R. Axel. 1979. Transformation of mammalian cells with genes from procaryotes and eucaryotes. Cell 16:777-785.

55. Yuasa, Y., S. K. Srivastava, C. Y. Dunn, J. S. Rhim, E. P. Reddy, and S. A. Aaronson. 1983. Acquisition of transforming properties of alternative point mutations within c-bas/has human proto-oncogene. Nature (London) 303:775-779. 